\title{
ARCHIWA POLSKICH SIŁ ZBROJNYCH NA ZACHODZIE
}

\section{Słowa kluczowe}

polskie archiwa wojskowe; archiwa PSZ; archiwa w II wojnie światowej

\section{Keywords}

Polish military archives; PAF archives; archives during World War 2

\section{Streszczenie}

Skutkiem klęski państwa polskiego poniesionej w kampanii wrześniowej 1939 r. był exodus za granicę setek tysięcy Polaków. Podczas internowania w Rumunii archiwiści z ewakuowanego Archiwum Wojskowego wystąpili z inicjatywą zorganizowania służby archiwalnej dostosowanej do warunków wojennych i realizującej zadania zabezpieczania na bieżąco dokumentacji wywiezionej z Polski oraz wytwarzanej na bieżąco przez instytucje wojskowe powołane na emigracji. W ramach udziału Polaków w walce przeciwko III Rzeszy, u boku aliantów organizowano regularne formacje zbrojne nazwane Polskimi Siłami Zbrojnymi na Zachodzie. Każda z nich miała w strukturze ko-

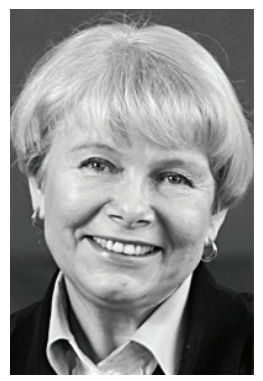

Wanda Krystyna Roman, profesor zwyczajny, pracuje w Zakładzie Zarządzania Dokumentacją i Informacji Archiwalnej Uniwersytetu Mikołaja Kopernika w Toruniu. Jej zainteresowania badawcze obejmują informację archiwalną, kulturę informacyjną i dokumentacyjną, archiwa polskie za granicą oraz archiwa wojskowe, internowanie Polaków podczas II wojny światowej, biografistykę oraz edytorstwo źródeł historycznych. Jest autorką m.in. monografii: Centralne Archiwum Wojskowe 1918-1998. Tradycje, historia, wspótczesność służby archiwalnej Wojska Polskiego (Toruń 1999) oraz ostatnio Wspótczesna kultura dokumentacyjna (Toruń 2013). E-mail: wandakr@umk.pl. 
mórki archiwalno-historyczno-muzealne. Były to m.in.: Referat Archiwalny w składzie odtworzonego Wojskowego Biura Historycznego w Armii Polskiej we Francji, Archiwum Sztabu Naczelnego Wodza w Londynie, komórki historyczno-archiwalne w lotnictwie i marynarce w Wielkiej Brytanii, Samodzielny Referat Historyczny Polskich Sił Zbrojnych przy Dowództwie Sił Zbrojnych w ZSRR, Archiwum Wojsk Polskich na Środkowym Wschodzie, Archiwum Armii Polskiej na Wschodzie, Archiwum i Muzeum Polowe Nr 1, Archiwum i Muzeum Polowe Nr 2, Archiwum Oddziału Informacyjnego 2 Korpusu Polskiego. Mnogość inicjatyw nie zawsze przekładała się na jakość pracy archiwów i archiwistów. Próbowano scentralizować zarządzanie placówkami archiwalnymi i muzealnymi PSZ, powołując w 1942 r. Archiwum i Muzeum Sił Zbrojnych w Szkocji, które jednak nie odegrało swojej roli z powodu braku zainteresowania najwyższych władz wojskowych. Podobnie było z powołaniem w styczniu 1945 r. Służby Archiwalno-Historycznej PSZ na Zachodzie. Sukcesem zakończyła się inicjatywa grupy osób, uwieńczona utworzeniem Instytutu Historycznego im. gen. W. Sikorskiego w Londynie w maju 1945 r. Ta placówka zrealizowała plany zgromadzenia w jednym miejscu - w miarę możliwości - dokumentacji wytworzonej przez polskie emigracyjne instytucje wojskowe i cywilne.

$\mathbb{W}$ Talki wrześniowe 1939 r. i klęska w wojnie z Niemcami, a następnie agresja Armii Czerwonej 17 IX 1939 r. zakończona zagarnięciem polskich ziem wschodnich przez ZSRR i późniejsze lata wojny były tragiczne w skutkach nie tylko dla państwa i narodu, ale również jego materialnego dziedzictwa kulturalnego, w tym dla zasobu archiwalnego ${ }^{1}$. Jednocześnie te same okoliczności stanowiły czynnik archiwotwórczy, ponieważ na obcej ziemi, w różnych okolicznościach powoływano polskie instytucje cywilne i wojskowe tworzące dokumentację, co wymagało podejmowania działań dotyczących jej zabezpieczenia. Walkę o zachowanie dokumentacji najczęściej podejmowali archiwiści i historycy, którzy często byli osamotnieni w swoich staraniach i trosce o pozostawienie trwałego śladu po tragicznych dla Polski i Polaków wydarzeniach i heroicznym wysiłku wojennym przy boku aliantów, nie znajdując zrozumienia u najwyższych władz.

Polskie Siły Zbrojne na Zachodzie (PSZ) jest nazwą nadaną regularnym formacjom wojskowym przez władze emigracyjne Rzeczypospolitej organizowanym poza granicami kraju na mocy umów z Francją i Wielką Brytanią zawartych w 1939 i 1940 r. i ze Związkiem Radzieckim w 1941 r. Były to: Ar-

1 Zasoby polskich archiwów zostały poważnie uszczuplone przez działania wojenne w 1939 r., walki i pożary (przypadkowe i celowe podpalanie przez Niemców) w powstaniu warszawskim, walki w okresie wyzwalania Polski spod okupacji niemieckiej w latach 1944-1945 oraz grabieże dokonywane zarówno przez Niemców, jak i Rosjan. 
mia Polska we Francji, 1 Korpus Polski w Anglii i sformowana na jego bazie 1 Dywizja Pancerna i Samodzielna Brygada Spadochronowa, Armia Polska w ZSRR pod dowództwem gen. Władysława Andersa, Wojsko Polskie na Środkowym Wschodzie, Armia Polska na Wschodzie oraz 2 Korpus Polski². Głównie dzięki staraniom archiwistów i historyków powołano w strukturach władz i formacji wojskowych wiele komórek mających na celu zabezpieczanie dokumentacji, które nie zawsze miały zapewnione odpowiednie - na miarę wojny - warunki do wykonywania swoich obowiązków. Problematyka archiwów PSZ jako całościowo nie była do tej pory przedmiotem szerszego zainteresowania badaczy. Ukazały się jedynie artykuły przyczynkarskie, głównie autorstwa Andrzeja Suchcitza ${ }^{3}$, niewielkie wzmianki znajdują się w biogramach archiwistów pracujących tam w okresie wojny ${ }^{4}$ oraz opracowywanych po wojnie publikacjach na temat Instytutu Historycznego im. gen. Władysława Sikorskiego w Londynie, gdzie znalazło swoje miejsce większość archiwaliów PSZ $^{5}$. Podstawowym źródłem informacji na temat archiwów PSZ pozostają archiwalia przechowywane we wspomnianym Instytucie, głównie w zespołach akt Armii Polskiej we Francji oraz 2 Korpusu Polskiego (2 KP). Wiele nie było do tej pory wykorzystywanych w badaniach naukowo-archiwalnych. Celem artykułu jest pokazanie zmian organizacyjnych archiwów powoływanych przy różnych formacjach PSZ w oparciu o archiwalia oraz dostępną literaturę przedmiotu. Nieodzownym aspektem dziejów archiwów są również ich zasoby, których charakterystyka została ograniczona do minimum z uwagi na zakres przekraczający ramy niniejszego artykułu.

2 M. Szczurowski, Mity, rytuały, symbole a żotnierz polski w przestrzeni politycznej II wojny światowej, Toruń 2013, s. 56-58.

${ }_{3}$ M.in.: A. Suchcitz, Sprawa odtworzenia Archiwum Wojskowego we Francji w 1940 r., „Teki Historyczne” (Londyn), t. 21, 1995; tenże, Powstanie Instytutu Historycznego im. Gen. Sikorskiego w Londynie 1945-1949, [w:] Idea Europy i Polska w XIX i XX wieku, red. J. Degler i in., Wrocław 1999.

${ }^{4}$ M.in.: M. Manteufflowa, Edmund Oppman, [w:] Polski słownik biograficzny, t. 24, red. E. Rostworowski, Wrocław-Kraków 1979; N. Bujniewicz, A. Zajas, Bronisław Pawłowski i Bolesław Waligóra - szefowie Archiwum Wojskowego w 20-leciu międzywojennym, [w:] Wkład archiwistów warszawskich $w$ rozwój archiwistyki polskiej, red. A. Kulecka, Warszawa 2012; J. Ciesielski, T. Wawrzyński, Waligóra Bolesław, [w:] Słownik biograficzny archiwistów polskich, t. 2: 1906-2001, red. B. Woszczyński, Warszawa 2002; Z. Rymaszewski, Adamus Jan, [w:] Słownik biograficzny archiwistów polskich, t. I: 1918-1984, red. M. Bielińska, I. Janosz-Biskupowa, Warszawa-Łódź 1988.

${ }_{5}$ M.in. E. Oppman, Historia powstania Instytutu Historycznego imienia generała Sikorskiego, jego cele i zadania, [w:] Instytut Historyczny imienia Generała Sikorskiego 1945-1957, Londyn 1957. 
Armia Polska we Francji została sformowana na podstawie polsko-francuskiej umowy wojskowej z 9 IX 1939 r. W jej składzie początkowo byli polscy emigranci zarobkowi, następnie stopniowo zaczęli napływać polscy żołnierze i oficerowie, którym udało się wydostać z kraju, głównie poprzez obozy internowania w Rumunii na Węgrzech, Litwie i Łotwie, do których trafili po kampanii wrześniowej. Była wśród nich grupa archiwistów i historyków wojskowych, przedwojennych pracowników Archiwum Wojskowego (AW) i Wojskowego Biura Historycznego (WBH) internowanych 17 IX 1939 r. w Rumunii6. Transportami ewakuacyjnymi, dowodzonymi przez kierownika AW Bolesława Waligórę i mjr. Ottona Laskowskiego z WBH, wywieźli oni z kraju kilkaset paczek akt, z których część na drodze ewakuacji uległa zniszczeniu, ale pozostałe udało się uratować i znalazły się w obozie internowania w rumuńskiej Tulczy .

Podczas pobytu w Rumunii mjr Waligóra próbował zainteresować władze wojskowe sprawą odtworzenia Archiwum Wojskowego (i Wojskowego Biura Historycznego) przy Naczelnym Dowództwie Armii Polskiej we Francji. W przedłożonym 2 XI projekcie powołania instytucji archiwalno-historycznej, którą on miałby kierować jako dyrektor, kustoszem proponował mianować kpt. dr. Jana Giergielewicza, biuro AW miałby prowadzić por. Marian Bourdon, a jednoosobowy wydział archiwalny kpt. Wiktor Brummer ${ }^{8}$ - przed wybuchem wojny wszyscy byli pracownikami AW i przebywali w Rumunii na internowaniu. Oprócz nich Waligóra proponował jednego oficera WBH, który miałby stanąć na czele referatu zajmującego się obecną wojną. Zadania archiwum miałyby pozostać takie same, jak przedwojennego AW: gromadzenie, przechowywanie i inwentaryzacja akt władz wojskowych i innych materiałów związanych z historią wojskową. Najważniejszą kwestią w memoriale Waligóry było podniesienie sprawy konieczności zbierania i przechowywania materiałów archiwalnych na potrzeby wojska w prowadzonej obecnie wojnie i ewentualnie jako doświadczeń na przyszłość ${ }^{9}$. Projekt pozostał na papierze, chociaż jeszcze w listopadzie spodziewano się, że uratowane z ogarniętego

6 W. K. Roman, Centralne Archiwum Wojskowe 1918-1998. Tradycje, historia, współczesność służby archiwalnej Wojska Polskiego, Toruń 1999, s. 49-50.

7 Szerzej: taż, Losy polskich akt wojskowych po wybuchu II wojny światowej-epizod rumuński 17. 09-19. 11. 1939 r. (w druku).

8 B. Waligóra, Archiwum Wojskowe od 31 sierpnia do 17 listopada 1939 roku, s. 21. Zob. Archiwum Instytutu Polskiego i Muzeum im. gen. W. Sikorskiego w Londynie (dalej AIPMS), Relacje z Kampanii 1939 r., sygn. B.I.12.H, s. 54.

9 Memoriał Bolesława Waligóry z 2 XI 1939 r., AIPMS, Akta z obozów internowanych. Dowództwo Obozów WP na terenie Rumunii, sygn. A.III.1/1. 
wojną kraju archiwalia zostaną przetransportowane do Paryża ${ }^{10}$. Ostatecznie ewakuowanie do Rumunii AW poskutkowało rozproszeniem materiałów, z których większa część, przez Bliski Wschód, Francję i Portugalię, została przewieziona do Stanów Zjednoczonych ${ }^{11}$.

Komórka archiwalna w strukturze Armii Polskiej we Francji powstała dopiero 4 III 1940 r. jako Referat Archiwalny w składzie odtworzonego $\mathrm{WBH}^{12}$. Bezpośrednim impulsem prawdopodobnie nie były zabiegi przedwojennego kierownika AW, ale narastający problem z aktami operacyjnymi z kampanii wrześniowej, które stopniowo zaczęto przekazywać z Bukaresztu do Paryża. Referat Archiwalny był jedynie namiastką dawnego AW, a jego rola została sprowadzona do - początkowo dwuosobowej ${ }^{13}$ - komórki z funkcjami usługowymi wobec WBH. To WBH, którego szefem został mjr Laskowski, miało jako naczelne zadanie: „zbieranie i przechowywanie dokumentów wg zasad archiwistyki [...] udzielanie odpisów akt"14. Ściągnięty z Rumunii pod fałszywym nazwiskiem mjr Waligóra ${ }^{15}$, mianowany kierownikiem Referatu Archiwalnego i zastępcą szefa WBH, od początku rozpoczął intensywne starania o stały lokal ${ }^{16}$, fundusze na zabezpieczenie i konserwację archiwaliów oraz próbował właściwie zorganizować wymienione w rozkazie zbieranie źródeł. Dość szybko zaczęto gromadzić przysyłane z różnych miejsc materiały dotyczące m.in. internowania w Rumunii i na Węgrzech oraz przechowywane przez różne komórki wojskowe.

Rozbudowa organizacyjna polskiego wojska na terenie Francji spowodowała, że przy wielu jednostkach organizowano archiwa oddziałowe, które docelowo miały trafić pod opiekę Referatu Archiwalnego w WBH. Tymczasem w maju 1940 r., kiedy archiwiści wreszcie byli organizacyjnie w miarę do-

10 A. Suchcitz, Sprawa odtworzenia Archiwum Wojskowego, s. 224.

11 Materiały te w większości znajdują się obecnie w zasobie archiwum Instytutu Józefa Piłsudskiego w Nowym Jorku. Instytut Józefa Piłsudskiego w Ameryce i jego zbiory, oprac. J. Cisek, Warszawa 1997, s. 39-40.

12 Rozkaz organizacyjny z 4 III 1940 r., AIPMS, Armia Polska we Francji 1939-1940. Wojskowe Biuro Historyczne w Paryżu, sygn. A.IV.5/2.

13 Początkowo w referacie pracowali mjr Waligóra i kpt. dr Jan Giergielewicz, jeszcze w Paryżu dołączył do nich (również z internowania w Rumunii) ppor. dr Edmund Oppman, przedwojenny pracownik AW. Patrz: M. Manteufflowa, dz. cyt, s. 145-146.

14 Rozkaz organizacyjny z 4 III $1940 \mathrm{r}$.

15 N. Bujniewicz, A. Zajas, dz. cyt., s. 400.

16 WBH początkowo ulokowano w pomieszczeniach Biblioteki Polskiej w Paryżu, a od maja 1940 r. przydzielono lokal przy ul. Poissy 4. J. Zuziak, Wojskowa służba historyczna na obczyźnie 1939-2002, [w:] Z dziejów służby historycznej Wojska Polskiego 1918-2002, Warszawa 2002, s. 55. 
brze przygotowani do podjęcia właściwej pracy, Niemcy zaatakowały Francję i Referat Archiwalny ewakuowano z Paryża do Angers. Tu podstawowym zadaniem Referatu miało być zgromadzenie wszystkich dotychczas przejętych materiałów ${ }^{17}$ oraz przejęcie zbędnych akt Biura Rejestracyjnego Ministerstwa Spraw Wojskowych (MSWojsk.) ${ }^{18}$. Klęski ponoszone przez Francję w walkach $\mathrm{z}$ armią niemiecką spowodowały przeniesienie Referatu Archiwalnego do Saintes, gdzie część akt spalono, a pozostałe odesłano statkiem do Wielkiej Brytanii ${ }^{19}$, gdzie ewakuowano naczelne władze cywilne i wojskowe oraz część żołnierzy armii polskiej ${ }^{20}$. Ten moment uznaje się za koniec WBH oraz AW w jego przedwojennej postaci. Mimo iż Waligóra surowo oceniał decyzje oraz faktyczną bierność emigracyjnych władz wojskowych w zakresie troski o archiwalia ${ }^{21}$, mimo że nie udało się sprawnie odtworzyć obu służb: archiwalnej i historycznej, to jednak zarówno jego wysiłki, jak i mjr. Laskowskiego z WBH doprowadziły do zabezpieczenia i uratowania nie tylko akt wywiezionych z Polski, ale i na bieżąco wytwarzanych przez instytucję, urzędy i jednostki wojskowe we Francji.

Ewakuowani z Francji żołnierze i oficerowie weszli w skład formowanego w Szkocji od sierpnia 1940 r. 1 Korpusu Polskiego (1 KP) ${ }^{22}$. Major Waligóra początkowo znalazł się w obozie wojskowym w okolicach miejscowości Douglas i formalnie pozostawał kierownikiem Referatu Archiwalnego. Szybko ściągnięto go do Londynu, gdzie ulokowano materiały archiwalne przewiezione z Francji i 28 VII 1941 r. został wyznaczony kierownikiem Archiwum Sztabu Naczelnego Wodza $(\mathrm{NW})^{23}$, którym był gen. Władysław Sikorski. Jednak nie próbowano odtwarzać WBH ani AW, a przedwojenny personel był rozproszo-

17 Było to m.in. kilkanaście skrzyń, które przyjechały z Bukaresztu.

18 Biuro Rejestracyjne utworzone w Paryżu na przełomie października i listopada 1939 r., kierowane przez płk. dypl. Franciszka Mallego, zajmowało się zbieraniem relacji od uczestników kampanii wrześniowej dla celów historycznych, ale nieformalnie miały to być dowody na winę władz przedwojennej Rzeczypospolitej za zaniedbania w obronie kraju i klęskę w wojnie z Niemcami.

19 A. Suchcitz, Sprawa odtworzenia Archiwum Wojskowego, s. 231.

${ }^{20}$ Pozostali, w tym prawie cała 2 Dywizja Strzelców Pieszych, trafili do obozów internowania w Szwajcarii.

${ }^{21}$ Tenże, Sprawa odtworzenia Archiwum Wojskowego, s. 231.

22 M. Szczurowski, dz. cyt., s. 56.

23 A. Suchcitz, Major Bolesław Andrzej Waligóra - pionier polskiej archiwistyki wojskowej, „Biuletyn Wojskowej Służby Archiwalnej”, nr 26, 2003, s. 26. 
ny w różnych obozach w Szkocji, pisząc listy do Waligóry z prośbami o wstawiennictwo w powrocie do pracy archiwalnej24.

Waligóra nie zdążył podjąć szerszych działań w zakresie „centralnego planu gospodarki aktami" 25 ani w kwestii zabezpieczania i gromadzenia materiałów historycznych, gdyż zginął podczas niemieckiego bombardowania Londynu 1 XI 1940 r. $^{26}$

Również jego następca, por. dr Edmund Oppman wyznaczony na stanowisko kierownika Archiwum Sztabu NW przez kpt. Stanisława Librewskiego $\mathrm{z} \mathrm{WBH}{ }^{27}$, niewiele zdziałał, gdyż władze wojskowe nie były zbyt zainteresowane sprawami archiwalnymi. Natomiast w Gabinecie NW doceniono wagę dokumentów jako dowodów na udział Polski w wojnie światowej i podjęto systematyczne gromadzenie materiałów historycznych do „Dziennika Czynności NW", który prowadziła jego adiutantura ${ }^{28}$. W tym okresie, z uwagi na bombardowania Londynu i zapewnienie bezpieczeństwa dokumentom, Archiwum Sztabu NW przeniesiono do Szkocji do miejscowości Gask, gdzie znajdowała się Kwatera Polowa NW ${ }^{29}$. Dopiero w 1941 r. zdecydowano, że na fundamencie tego archiwum winno powstać archiwum centralne z zadaniem „gromadzenia, zachowania i zabezpieczenia materiałów z współcześnie toczącej się

${ }^{24}$ N. Bujniewicz, A. Zajas, dz. cyt., s. 400.

25 E. Oppman, dz. cyt., s. 6.

${ }^{26}$ Był członkiem biernej obrony przeciwlotniczej. J. Ciesielski, T. Wawrzyński, dz. cyt., s. 190.

27 S. Librewski, Początki centralnego archiwum na obczyźnie, „Tydzień Polski”, 27 IV 1968, s. 7.

28 Pomysł „Dziennik Czynności NW” powstał wskutek obserwacji pracy i zwyczajów gen. Sikorskiego, który własnoręcznie pisał przemówienia czy referaty, oraz jego współpracowników, który m.in. prowadzili obserwację prasy. Dziennik czynności składał się z czterech działów: Przebieg dnia Generała, Załączniki do tego działu, Fotografie do danego dnia, Wycinki z gazet. Całość koordynowali Edmund Oppman i jego żona Regina, których zatrudniono, tworząc archiwum przy szkockiej kwaterze gen. Sikorskiego. Pomysłodawcą był ppłk Zygmunt Borkowski, który oprócz Oppmanów był jedyną osobą, która wiedziała o Dzienniku. Z. Borkowski, Wspomnienia 1939-1943, „Zeszyty Historyczne” (Paryż), z. 31, 1975, s. 129.

${ }^{29}$ Gask był miejscem, które wybrano - jako bezpieczne - na zorganizowanie kwatery NW. Jak pisał Zygmunt Borkowski: „Wielką zaletą Gasku były puste budynki gospodarskie, do których mogłem stopniowo przenosić rozrzucone po całej Szkocji dokumenty wojskowe i państwowe ocalałe z Francji. Tak samo udało mi się zebrać wszystkie sztandary pułkowe uratowane z kampanii wrześniowej. Wreszcie powstały tam zaczątki muzeum i biblioteki. Pod koniec życia gen. Sikorskiego, służąc mu nadal jako kwatera, Gask stał się równocześnie warsztatem pracy dla historyków”. Z. Borkowski, dz. cyt., s. 131. 
wojny” jako „kardynalny obowiązek wobec potomności”30. Jednak sprawy archiwalne pojawiły się w zasięgu bliższego zainteresowania wyższych władz wojskowych znacznie później.

Rozkazem gen. Sikorskiego wydanym na początku 1942 r., a będącym wynikiem inspekcji archiwum w Kwaterze Polowej, zorganizowano w jej siedzibie Archiwum Sił Zbrojnych (SZ) z referatem muzealnym (nazywane również Archiwum i Muzeum SZ) podlegające szefowi Gabinetu NW ${ }^{31}$. Zasadniczym jego celem było zgromadzenie całości dokumentacji centralnych władz i oddziałów wojskowych z terenu Wielkiej Brytanii, Francji, Norwegii, Holandii i Niemiec ${ }^{32}$. Jednocześnie powołano komórki historyczno-archiwalne w lotnictwie i marynarce, które miały podobne zadania w odniesieniu do tych rodzajów sił zbrojnych. Tym samym powstały formalne podstawy do podjęcia planowej i całościowej akcji zabezpieczania materiałów historycznych, do której zamierzano dokooptować emigracyjne instytucje cywilne. Podczas zjazdu w Gasku w kwietniu 1942 r. z udziałem władz cywilnych i wojskowych uzyskano wszechstronne poparcie dla inicjatywy archiwalnej, obietnicę współpracy oraz - co szczególnie było wówczas ważne - zdecydowano o przyznaniu funduszy na działalność Archiwum SZ ze strony zainteresowanych instytucji. Cele i zadania Archiwum i Muzeum SZ ustalał rozkaz gen. Sikorskiego z 11 V 1942 r. ${ }^{33}$ Nowa placówka obejmowała archiwum, muzeum oraz bibliotekę. Całość prac była koordynowana przez Gabinet NW. Wkrótce opracowano wytyczne gromadzenia materiałów historycznych dla Archiwum oraz biur historycznych marynarki i lotnictwa. W celu odciążenia m.in. dowództw i sztabów od nadmiaru akt i zabezpieczenia akt o wartości historycznej przed zniszczeniem lub rozproszeniem nałożono na nie obowiązek odsyłania akt do nowo powołanego Archiwum SZ przy Gabinecie NW. Akta Marynarki Wojennej (MW) miały być przekazywane do Biura Historycznego MW, które po „przepracowaniu i wykorzystaniu” miało je przekazać do Archiwum SZ. Tam też miały trafić akta z Biura Historycznego Lotnictwa ${ }^{34}$.

30 E. Oppman, dz. cyt., s. 6-7.

31 Tamże, s. 7.

${ }^{32}$ R. Oppmanowa, Archiwum, [w:] Instytut Historyczny imienia Generała Sikorskiego, s. 21.

${ }^{33}$ E. Oppman, dz. cyt., s. 8.

34 Tymczasowa instrukcja o gromadzeniu, wydzielaniu, przekazywaniu i przechowywaniu akt. Wyciąg z Dziennika Rozkazów NW i MSWojsk. nr 6 z 15 X 1942 r., AIPMS, 2 Korpus Polski (dalej 2 KP), sygn. A.XI.57/10. 
Z końcem 1942 r., z inicjatywy szefa Gabinetu NW, nawiązano kontakty z archiwistami, historykami i muzealnikami z Armii Polskiej na Środkowym Wschodzie, gdzie zabezpieczanie dokumentów i eksponatów trwało nieprzerwanie od momentu znalezienia się tam ewakuowanych z ZSRR polskich formacji wojskowych.

Armia Polska w ZSRR została sformowana w wyniku podpisania 30 VII 1941 r. układu polsko-radzieckiego (zwanego układem Sikorski-Majski) ${ }^{35}$. W jej szeregach znaleźli obywatele polscy przebywający na terenach radzieckich jako jeńcy wojenni wzięci do niewoli po 17 IX 1939 r. bądź deportowani w latach 1939-1941. Na czele armii stanął gen. Władysław Anders zwolniony 4 VIII 1941 r. z więzienia NKWD na Łubiance ${ }^{36}$. Tuż po zawarciu umowy, jeszcze podczas pobytu w obozie NKWD w Griazowcu grupa oficerów, byłych jeńców wojennych poddała myśl gromadzenia materiałów i pamiątek historycznych oraz zorganizowania komórki na wzór przedwojennego WBH. W oparciu o tę inicjatywę gen. Anders powierzył inicjatorom pomysłu zorganizowanie w swoim sztabie referatu historycznego. Organizację i zadania Samodzielnego Referatu Historycznego Polskich Sił Zbrojnych przy Dowództwie Sił Zbrojnych w ZSRR uregulował rozkaz gen. Andersa z 17 XII 1941 r. Kierownikiem referatu został por. dr Walerian Charkiewicz. Pierwszym zadaniem referatu było utworzenie Archiwum Polskich Sił Zbrojnych w ZSRR, a w jego kilkuosobowym składzie znalazło się stanowisko archiwariusza ${ }^{37}$. Pozostałe zadania archiwalne Referatu Historycznego dotyczyły zbierania i porządkowania dokumentów i innych materiałów historycznych odnoszących się do organizacji, życia i walk PSZ w ZSRR, zbierania relacji, prowadzenia ewidencji żołnierzy zmarłych i poległych, przechowywania akt archiwalnych zgodnie z przepisami przedwojennego WBH i AW, kierowania pracami archiwalno-kronikarskimi w dywizjach ${ }^{38}$.

Wiosną 1942 r., w wyniku zabiegów rządu angielskiego, zapadła decyzja o ewakuacji armii polskiej z ZSRR do Iranu ${ }^{39}$. Pojawienie się wielotysięcznego wojska w Iranie spowodowało potrzebę zmiany koncepcji i przeorganizowania polskich jednostek wojskowych, które istniały w tym rejonie wcze-

35 P. Żaroń, Armia Andersa, Toruń 1996, s. 35-36.

36 W. Anders, Bez ostatniego rozdziału. Wspomnienia z lat 1939-1946, Londyn 1960, s. 60.

37 Rozkaz nr 13 z 17. 12. 1941 r., AIPMS, 2 KP, sygn. A.XI.57/10.

38 Tamże.

39 P. Żaroń, dz. cyt., s. 115-120. 
śniej: Brygady Strzelców Karpackich w Syrii (potem Palestynie i Egipcie) od kwietnia 1940 roku, a potem 2 Korpusu Strzelców. Jednostkami tymi, w ramach Wojska Polskiego na Środkowym Wschodzie, dowodził gen. Józef Zając ${ }^{40}$. W obu jednostkach istniały komórki archiwalne. Dowódca Ośrodka Zapasowego na Środkowym Wschodzie gen. Kordian Zamorski 18 VI 1941 r. meldował gen. Stanisławowi Kopańskiemu, dowódcy Brygady Strzelców Karpackich, o utworzeniu „archiwum”, a tenże kilka dni później zaakceptował powstanie tej komórki oraz jej skład osobowy ${ }^{41}$. Faktycznie archiwum wówczas nie utworzono i dopiero zabiegi kierownika Ekspozytury Szefa Intendentury Sztabu NW na Środkowym Wschodzie płk. Witka doprowadziły do utworzenia w październiku 1941 r. Archiwum Wojsk Polskich na Środkowym Wschodzie ${ }^{42}$. Tak zwany list fundacyjny archiwum, czyli rozkaz gen. Zająca z 21 VIII 1942 r., podkreślał naukowo-historyczny charakter archiwum ${ }^{43}$. Stanowisko zarządcy archiwum objął kpt. W. Romanow ${ }^{44}$. Zawiązkiem zasobu archiwum były depozyty prywatne osób wojskowych, oddziałów i instytucji wojskowych nadsyłane za pośrednictwem ambasady polskiej w Bukareszcie do Brygady Strzelców Karpackich w Syrii oraz akta tej brygady ${ }^{45}$. Od sierpnia 1942 r. do archiwum przekazywano również archiwalia oddziałów, komend i garnizonów Armii Polskiej w ZSRR, które poddawano reorganizacji.

We wrześniu 1942 r. została zatwierdzona nowa organizacja wojska na Środkowym Wschodzie, które odtąd miało funkcjonować jako Armia Polska na Wschodzie (APW), a jej dowódcą mianowano gen. Andersa. Równocześnie na filarach istniejącego archiwum powołano Archiwum APW ze stałą siedzibą w Jerozolimie. W listopadzie 1942 r. inspekcję placówki przeprowadził kierownik Referatu Historycznego kpt. dr Charkiewicz i podjął decyzję o obsadzie kierownictwa trzech działów: archiwalnego, muzealnego i bibliotecznego. Kierownikiem Archiwum APW został historyk prawa i przedwojenny archiwista Archiwum Miejskiego w Wilnie kpt. dr Jan Adamus ${ }^{46}$. Ofi-

40 Tamże, s. 167.

41 Sprawozdanie o stanie Archiwum Armii Polskiej na Wschodzie w dniu 15 XI 1943 r., AIPMS, 2 KP, sygn. A.XI.57/10.

42 Notatka służbowa „Archiwum Armii Polskiej na Wschodzie” z 7 VIII 1943 r., AIPMS, 2 KP, sygn. A.XI.57/10.

43 Tamże.

44 Sprawozdanie o stanie Archiwum APW.

45 Tamże.

46 Uwagi o organizacji i pracy Samodzielnego Referatu Historycznego i Archiwum APW z 25 VII 1944 r., AIPMS, 2 KP, sygn. A.XI.57/6. Jan Adamus wrócił do Polski w 1949 r., ale w artykułach biograficznych, które ukazały się pośmiertnie, jego losy 
cjalnie nominację otrzymał od 1 I 1943 r., chociaż obowiązki sprawował już od 14 XII 1942 r. ${ }^{47}$ Ponadto w Archiwum APW zatrudniono docenta Uniwersytetu Poznańskiego por. rez. dr. Leona Koczego jako referenta archiwalnego $^{48}$, jego zastępcę byłego urzędnika Archiwum Akt Dawnych m. Krakowa sierż. rez. dr. Jana Krupę, przedwojennego współpracownika Muzeum Wojska por. rez. Jana Domańskiego jako referenta muzealnego, jego zastępcę byłego kustosza Muzeum w Truskawcu kapr. rez. Jarosława Sagana oraz por. rez. dr. Błażeja Skrzyńskiego ${ }^{49}$. Referat archiwalny obejmował trzy działy: akt i dokumentów, druków i plakatów oraz kartograficzny.

Rozkazem gen. Andersa z 20 II 1943 r. podporządkowano wspomniane archiwum kierownikowi Biura Historycznego, powstałego w wyniku przekształcenia Samodzielnego Referatu Historycznego PSZ w ZSRR ${ }^{50}$. Status Archiwum APW określono jako składnicę archiwalno-muzealną, organ wykonawczy Biura Historycznego oraz filię Centralnego Archiwum Sił Zbrojnych ${ }^{51}$. Placówkę wkrótce przeniesiono z Jerozolimy do Rehovotu ${ }^{52}$, a do zakończenia wojny archiwum jeszcze 10 razy zmieniało miejsce postoju ${ }^{53}$.

W Rehovot pomieszczenia archiwalne ulokowano w samodzielnej willi, ale narzekano na panującą w nich zbyt dużą wilgotność oraz oddalenie od bibliotek i muzeów. Praca archiwistów polegała na gromadzeniu, porządkowaniu i spisywaniu wszelkich dokumentów, które przejmowano na bieżąco i w pośpiechu, gdyż jednostki wojskowe nie mogły tworzyć swoich registratur ${ }^{54}$. We

w latach wojny zostały prawie całkowicie przemilczane. Zob.: K. Tymieniecki, Jan Adamus (1896-1962), „Roczniki Historyczne”, t. 30, 1964, s. 263-265; J. Bardach, Jan Adamus (1896-1962) - próba charakterystyki naukowej, „Czasopismo Prawno-Historyczne”, t. 15, 1963, z. 1, s. 327-332; K. Koranyi, Jan Adamus (1896-1962), „Kwartalnik Historyczny”, R. 70, 1963, s. 523-525; H. Grajewski, Jan Adamus (1896-1962), „Zeszyty Naukowe Uniwersytetu Łódzkiego", seria I, z. 31, 1963, s. 179-194. Nieco więcej informacji przynosi biogram z 1988 r. (Z. Rymaszewski, dz. cyt., s. 21-22), a dokładniej pisze o wojennym okresie życia Adamusa Juliusz Bardach, zob. J. Bardach, Jana Adamusa wspominam..., „Czasopismo Prawno-Historyczne”, t. 49, 1997, s. 163-173.

47 J. Bardach, Jana Adamusa wspominam, s. 169.

48 R. Stobiecki, Leon Koczy, „Teki Historyczne”, t. 23, 2004, s. 276.

49 Notatka służbowa „Archiwum Armii Polskiej na Wschodzie”.

50 Tamże.

51 Instrukcja dla kierownika Archiwum Armii Polskiej na Wschodzie, AIPMS, 2 KP, sygn. A.XI.57/10. Centralnym Archiwum nazywano funkcjonujące w Szkocji Archiwum i Muzeum Sił Zbrojnych.

52 Tamże.

${ }^{53}$ R. Stobiecki, dz. cyt., s. 276.

54 Stan archiwum na sierpień 1942 r. obejmował 69 skrzyń z aktami, w tym 26 uporządkowanych. Tamże. 
sierpniu 1944 r. odwołano z funkcji kierownika Jana Adamusa, który został oddelegowany do Archiwum i Muzeum SZ w Szkocji jako jego kierownik ${ }^{55}$. Archiwum APW przejął dr Leon Koczy ${ }^{56}$ i to on zmagał się z kolejnymi przeprowadzkami: z powrotem do Jerozolimy i w marcu 1944 r. do Tel Awiwu ${ }^{57}$.

W lipcu 1943 r. doszło do reorganizacji wojska polskiego, w wyniku której powołano dowództwo 2 KP. Dowódca Korpusu gen. Anders jednocześnie pozostał dowódcą Armii Polskiej na Wschodzie ${ }^{58}$. Od grudnia 1943 r. przez kilka miesięcy trwało przerzucanie sił polskich do Włoch w celu wspomożenia wojsk alianckich przy łamaniu niemieckich pozycji obronnych. Od lutego 1944 r. archiwum przygotowywało się do usamodzielnienia w związku z planami odejścia Biura Historycznego do Włoch wraz z wojskiem. Jednak do lipca 1944 r. nic w tej mierze się nie dokonało, natomiast znacznie pogorszyła się sytuacja personalna i wyraźnie odczuwano lekceważący stosunek przełożonych do pracy historyczno-archiwalnej. W raporcie do Dyrektora Archiwum i Muzeum SZ w Szkocji Leon Koczy z goryczą pisał, że „Archiwum, traktowane w pierwszym okresie swego istnienia jako schronisko dla inwalidów, do dnia dzisiejszego nieraz bywa uważane za instytucję, która może zapewnić wygodny przydział ludziom unikającym pracy"59, jednocześnie podkreślał brak kwalifikacji i rotację przydzielanych pracowników (5 oficerów, 7 szeregowych i 3 ochotniczki) oraz brak zrozumienia odnośnie do tego, że personel służby historyczno-archiwalnej powinien być fachowy, doświadczony i dobrze wykształcony. Koczy uważał również za błąd pozostawanie obu służb: archiwalnej i historycznej, w oderwaniu od jednostek $2 \mathrm{KP}$, czego skutkiem mogło być zniszczenie lub zaginięcie wielu akt i pamiątek. Dlatego m.in. w wyniku kontaktów listownych Instytutu Józefa Piłsudskiego w Nowym Jorku ${ }^{60} \mathrm{z}$ od-

55 J. Bardach, Jana Adamusa wspominam, s. 169.

${ }^{56}$ R. Stobiecki, dz. cyt., s. 276.

57 Uwagi o organizacji i pracy Samodzielnego Referatu Historycznego i Archiwum APW z 25 VII 1944 r.

58 P. Żaroń, dz. cyt., s. 213-214.

59 Uwagi o organizacji i pracy Samodzielnego Referatu Historycznego i Archiwum APW z 25 VII 1944 r.

${ }^{60}$ Instytut Józefa Piłsudskiego w Nowym Jorku powołano 4 VII 1943 r. jako swego rodzaju reaktywację podobnej placówki istniejącej w Warszawie przed wybuchem wojny. Jednym z podstawowych jego zadań miało być pozyskiwanie archiwaliów. Na zbiory Instytutu (dary i depozyty) składają się materiały przedwojennego Instytutu Józefa Piłsudskiego w Warszawie, archiwalia polskich placówek dyplomatycznych z lat wojny, materiały organizacji polskich w USA, spuścizny archiwalne oficerów i polityków polskich z okresu wojny oraz działaczy polonijnych, polskich emigrantów - naukowców i twórców kultury. Instytut Józefa Piłsudskiego w Ameryce, s. 88. 
działem oświatowo-kulturalnym $2 \mathrm{KP}$, jeszcze podczas działań wojennych, przekazywano tam oprócz periodyków, także dokumenty ${ }^{61}$.

We wrześniu 1944 r. odbył się zjazd w Wielkiej Brytanii poświęcony sprawom archiwalno-muzealnym, w którym uczestniczyli przedstawiciele wszystkich placówek i komórek zajmujących się tą problematyką. Miał on doprowadzić do zorganizowania jednolitego kierownictwa całością oraz skoordynowania wysiłków dotyczących zabezpieczania materiałów historycznych ${ }^{62}$. W wyniku zjazdu w październiku 1944 r. doszło do reorganizacji służby historyczno-archiwalnej, o którą zabiegał przede wszystkim minister obrony narodowej gen. Marian Kukiel ${ }^{63}$. Organem centralnym miało być Archiwum i Muzeum SZ w Szkocji. Przy korpusach miały powstać archiwa i muzea polowe podporządkowane ministrowi przez szefa Archiwów i Muzeów SZ. Autonomiczne biura historyczne miały pozostać w lotnictwie i marynarce ${ }^{64}$.

Zamierzenia zjazdu zrealizowano częściowo i w październiku 1944 r. powołano dwie placówki. Biuro Historyczne przeorganizowano w Archiwum i Muzeum Polowe Nr 1 (AMP Nr 1) z zadaniem obsługiwania 2 KP z siedzibą w Cezarei. Jego kierownikiem został kpt. dr Walerian Charkiewicz, dotychczasowy kierownik Biura Historycznego. Z kolei Archiwum APW przekształcono w Archiwum i Muzeum Polowe Nr 2 (AMP Nr 2) z siedzibą początkowo w Tel Awiwie, następnie w Kairze, które miało obsługiwać planowany 3 Korpus $^{65}$. Kierownikiem tej placówki archiwalnej pozostał Leon Koczy.

Obie placówki pracowały w niezwykle trudnych i niekorzystnych warunkach - brak odpowiednich lokali, niewykwalifikowany personel i ogólne warunki życia (np. pracownicy AMP Nr 2 nieraz mieszkali w namiotach), brak zrozumienia u przełożonych, trudności finansowe, wszystko to komplikowało podejmowanie prac archiwalnych ${ }^{66}$. AMP Nr 1 (używano również nazwy: AMP 2 Polskiego Korpusu) pod koniec 1944 r. przeniesiono z Cezarei do Ne-

61 W. Stępniak, Archiwalia polskie w zbiorach Instytutu Hoovera Uniwersytetu Stanforda, Warszawa 1997, s. 173-177.

62 E. Oppman, dz. cyt., s. 9.

63 Generał Marian Kukiel we wrześniu 1942 r. stanął na czele Ministerstwa Spraw Wojskowych, które w listopadzie tego roku zostało przemianowane na Ministerstwo Obrony Narodowej. J. Zuziak, Generał dywizji Marian Kukiel jako minister obrony narodowej (1942-1949), „Teki Historyczne” (Londyn), t. 21, 1994-1995, s. 266.

64 Raport Waleriana Charkiewicza do gen. W. Andersa z 20 II 1945 r., AIPMS, 2 KP, sygn. A.XI.57/6.

65 Tamże.

66 Tamże. 
apolu ${ }^{67}$. Ulokowano je w dość katastrofalnych warunkach i szef sztabu Korpusu sugerował przeniesienie archiwum do Rzymu i umieszczenie w budynku Polskiego Oficera Łącznikowego ${ }^{68}$. Początkowo siedemnastoosobowy personel zmniejszył się w styczniu 1945 r. do pięciu osób. Do marca 1946 r. liczba zatrudnionych w AMP Nr 2 wahała się w granicach 9-13 osób, w tym 3-5 oficerów ${ }^{69}$.

Na początku 1945 r. Charkiewicz w raporcie do gen. Andersa krytycznie podsumował efekty reorganizacji i podkreślił brak konsekwencji w działaniu zwierzchników, który doprowadził do rozbicia służby historyczno-archiwalnej przy jednoczesnym braku formalnego powiązania nowo utworzonych archiwów z centralnym archiwum i muzeum na ziemi brytyjskiej. Charkiewicz postulował, aby - w trosce o dokumenty - dowódca Korpusu powołał oficera do zleceń w sprawach archiwalno-muzealnych, analogicznie, jak było to w Armii Polskiej w ZSRR, z uwagi na rozproszenie tych kompetencji w 2 KP między kilka instytucji (komórek), w obowiązkach których znajdowało się gromadzenie i przechowywanie materiałów mających znaczenie historyczne. Były to: Biuro Dokumentów w Oddziale Informacyjnym APW i archiwum tegoż oddziału, Oddział Kultury i Prasy, Szefostwo Służby Sprawiedliwości oraz Biuro Rozrachunkowe APW. Na szczególną uwagę zasługuje Biuro Dokumentów powołane rozkazem Dowódcy APW 15 IV 1943 r. ${ }^{70}$ w celu zebrania materiału dotyczącego postępowania bolszewików na terenie części okupowanej przez nich Rzeczypospolitej, udokumentowania losów i przeżyć ludności polskiej na tym obszarze oraz po wywiezieniu w głąb Rosji, przygotowania dokumentów na konferencję pokojową oraz opracowania materiałów wydawniczych ${ }^{71}$. Po reorganizacji Biura w lutym 1944 r. jego zadania obejmowały prowadzenie Archiwum Oddziału Informacyjnego (Intelligence Archives Security), zbieranie, ewidencjonowanie oraz opracowywanie dokumentów przekazywanych przez właściwe organy i władze, przechowywanie depozytów żołnierzy APW o tajnym charakterze dokumentarnym, o ile nie stanowiły depozytów archi-

${ }^{67}$ Meldunek szefa sztabu Korpusu ppłk. dypl. Kazimierza Wiśniowskiego do szefa Oddziału Kultury i Prasy 2 Korpusu Polskiego z 25 II 1945 r., AIPMS, 2 KP, sygn. A.XI.57/6.

68 Tamże.

69 Personel AMP Nr 1 od stycznia 1945 r. do marca 1946 r., AIPMS, 2 KP, sygn. A XI.57/6.

70 Po ogłoszeniu przez radio niemieckie informacji o odkryciu grobów katyńskich.

71 K. Zamorski, Dwa tajne Biura 2 Korpusu, Londyn 1990, s. 12-15. 
walnych w pojęciu ogólnowojskowym ${ }^{72}$. Działalność Biura Dokumentów była krytycznie oceniana z powodu braku efektów, jak chociażby niewydanie żadnej publikacji oraz przekształcenie się w „swego rodzaju archiwum o bardzo licznym personelu i dużych pretensjach" dysponujące wartościowym, ale nieuporządkowanym zbiorem dokumentów ${ }^{73}$.

Do wdrażania w życie planu jednolitej organizacji działań służby archiwalno-muzealnej PSZ najwyższe władze wojskowe przystąpiły dopiero na początku 1945 r. Rozkazem z 26 I 1945 r. minister obrony narodowej wyznaczył szefem Służby Archiwalno-Historycznej PSZ na Zachodzie ppłk. Zygmunta Borkowskiego $^{74}$. Kolejnym krokiem było wdrożenie nowej instrukcji o przekazywaniu dokumentów, akt i pamiątek wojennych, w której zobowiązano wszystkich dowódców jednostek SZ do przekazywania organom Służby Archiwalno-Historycznej akt i dokumentów będących wytworem działalności SZ (po wykorzystaniu do bieżącej pracy lub walki), instrukcji, regulaminów, druków, czasopism, ulotek, afiszy (od razu po wydaniu), druków cudzych nabytych lub otrzymanych (po wykorzystaniu), przedmiotów będących zdobyczą wojenną (po wykorzystaniu), fotografii i filmów, materiałów artystycznych i propagandowych innych materiałów o wartości historycznej lub ogólnokulturalnej będących własnością SZ ${ }^{75}$. Podkreślano, że materiały mają być przekazywane uporządkowane wraz ze spisem w dwóch egzemplarzach, a akta wraz z dziennikami podawczymi. Dopuszczano również możliwość przejmowania materiałów od osób prywatnych jako dary na rzecz zbiorów publicznych lub określonej przez dysponenta instytucji lub jako depozyty do zwrotu „po powrocie do kraju”76.

Zadania postawione przez ppłk. Borkowskiego podległym placówkom archiwalnym, muzealnym i bibliotecznym miały być realizowane w sposób ujednolicony i skoordynowany oraz prowadzić do scalenia wszystkich materiałów dotyczących całości wojska, zarówno dotyczących sfery militarnej, jak i politycznej bez naruszania układu archiwalnego. Podpułkownik Borkowski podkreślał potrzebę zatrudnienia w archiwach wykwalifikowanego persone-

72 Organizacja Biura Dokumentów APW z 4 II 1944 r., AIPMS, 2 KP, sygn. A.XI.57/6.

73 Notatka rtm. Z. Stahla o Biurze Dokumentów dla Dowódcy 2 Korpusu z 21 I 1946 r., AIPMS, sygn. A.XI.57/4.

74 Wytyczne prac służby archiwalno-historycznej z 15 III 1945 r. Ppłk Zygmunt Borkowski był szefem Gabinetu NW od 1940 r. aż do śmierci gen. Sikorskiego w 1943 r., AIPMS, sygn. A.XI.57/4.

75 Instrukcja z 11 II 1945 r., AIPMS, sygn. A.XI.57/10.

76 Tamże. 
lu począwszy od kierowników aż do woźnych. Uzupełnieniem zadań dotyczących wojska miało zabezpieczanie przez archiwa, muzea i biblioteki wojskowe dla dobra sprawy polskiej innych, np. cywilnych materiałów w sytuacji, gdy nie miał kto się nimi zaopiekować. Archiwum miało segregować i inwentaryzować „akta i dokumenty, rękopisy, akta sądowe” według schematu opartego na organizacji sił zbrojnych i podziału na odrębne okresy chronologiczne (np. wrzesień 1939, Francja, Rosja) oraz z przestrzeganiem zasady proweniencji. W wyniku tych prac miały powstać inwentarze wraz ze skorowidzami.

W marcu 1945 r. nowy szef nakazał kierownikom AMP Nr 1 i Nr 2 przekazanie materiałów dotyczących całości sił zbrojnych oraz zagadnień ogólnowojskowych i politycznych do Archiwum i Muzeum SZ w Szkocji oraz rozpoczęcie akcji rewindykacyjnej materiałów archiwalnych, muzealnych i bibliotecznych, które nieprawnie przechowywane były „poza zasięgiem służby archiwalno-historycznej"77.

W ślad za wspomnianą instrukcją i wytycznymi szefa Służby Archiwalno-Historycznej, w kwietniu 1945 r. Dowództwo Jednostek Wojska na Środkowym Wschodzie wydało rozkaz dla podległych jednostek dotyczący gromadzenia i przechowywania akt i pamiątek historycznych szczegółowo regulujący kwestie odnośnie do przekazywania ich placówkom Służby Archiwalno-Historycznej. Przewidywano kontrolowanie tych prac w jednostkach przez kierownika AMP Nr 2, który miał regularnie zdawać raporty o stanie gromadzenia i zabezpieczania archiwaliów i - jako dodatkowy obowiązek - postępach prac kronikarskich, które miał nadzorować ${ }^{78}$.

Koniec wojny oznaczał rozformowanie formacji i jednostek PSZ na Zachodzie, chociaż nie stało się to od razu ${ }^{79}$. Polacy pozostający poza krajem w chwili zakończenia działań wojennych ${ }^{80}$ musieli zdecydować - wracać czy nie wracać do kraju. Na wielu decyzjach zaważyły postanowienia konferencji w Jałcie z lutego 1945 r. Wówczas przedstawiciele trzech wielkich mocarstw: Franklin Delano Roosevelt, prezydent USA, Winston Churchill, premier Wielkiej Brytanii i przywódca ZSRR Józef Stalin porozumieli się w sprawach o podstawo-

77 Wytyczne prac służby archiwalno-historycznej z 15 III 1945 r.

78 Rozkaz o gromadzeniu i przechowywaniu akt i pamiątek historycznych z 6 IV 1945 r., AIPMS, sygn. A.XI.57/10.

79 Przez wiele kolejnych miesięcy po zakończeniu działań wojennych polskie jednostki stacjonowały we Włoszech, Wielkiej Brytanii, Niemczech i na Bliskim Wschodzie.

${ }^{80}$ Było to ponad 1,5 miliona osób, w tym prawie 250 tysięcy żołnierzy PSZ. W. Roszkowski, Historia Polski 1914-2005, Warszawa 2007, s. 168-169. 
wym znaczeniu dla powojennego kształtu Europy, m.in. zdecydowali o okupacji Niemiec; zaakceptowali utratę przez Polskę Kresów Wschodnich na rzecz ZSRR, a Polsce przyznali rekompensatę w postaci Pomorza Zachodniego, Prus Wschodnich i Śląska oraz dokonali nieformalnego podziału stref wpływów, w wyniku którego ZSRR otrzymał „zwierzchnictwo” m.in. nad Polską i jedną trzecią Niemiec. W Jałcie mocarstwa zachodnie zgodziły się na utworzenie w Warszawie Tymczasowego Rządu Jedności Narodowej, a w lipcu cofnęły uznanie dla polskiego rządu emigracyjnego. Był to czas rozterek dla żołnierzy PSZ, powrót do Polski oznaczał bowiem życie w ujarzmionej ojczyźnie poddanej radzieckiej kontroli. Z kolei decyzja o pozostaniu na obczyźnie dla wielu wyższej rangi polityków i wojskowych łączyła się z kontynuowaniem państwa polskiego w warunkach emigracyjnych.

Oświadczenie rządu polskiego w Londynie o likwidacji PSZ ukazało się 24 V 1946 r., a następnego dnia wydano rozkaz przygotowawczy dowództwa 2 KP o przesunięciu całości sił do Wielkiej Brytanii ${ }^{81}$.

Równocześnie pojawił się problem zabezpieczenia dokumentacji polskich władz cywilnych wojskowych na uchodźstwie, w tym Prezydenta RP, rządu i szeregu instytucji cywilnych oraz akt PSZ, począwszy od władz najwyższych po najmniejsze jednostki i oddziały, aby „nie rozproszyły się, nie marnowały, nie przepadły"82. Dla trwania polskości na emigracji, dla ocalenia wkładu Polaków w wysiłek zbrojny drugiej wojny światowej u boku aliantów postanowiono o zabezpieczeniu wszystkich pamiątek archiwalnych, muzealiów i wydawnictw w instytucjach powołanych w tym celu na uchodźstwie. Próbowano m.in. zabezpieczyć materiały archiwalne dotyczące konspiracyjnej działalności Armii Krajowej przez zorganizowanie odrębnej komórki przy szefostwie Służby Archiwalno-Historycznej, na co nie wyraził zgody gen. Kukiel ${ }^{83}$.

Na początku 1945 r., jeszcze zanim zakończyły się działania wojenne, szef Służby Archiwalno-Historycznej PSZ na Zachodzie ppłk Zygmunt Borkowski wystąpił z inicjatywą powołania samodzielnego archiwum wojskowego w celu dawania świadectwa działalności gen. Sikorskiego i służeniu

81 B. Łokaj, Likwidacja Polskich Sił Zbrojnych 1945-1946, „Zeszyty Historyczne” (Paryż), z. 35, 1976, s. 50-51, 59.

${ }^{82}$ M. Kukiel, Słowo wstępne, [w:] Instytut Historyczny imienia Generała Sikorskiego, s. 3 .

83 W 1947 r. powołano w tym celu samodzielne Studium Polski Podziemnej z siedzibą w Londynie. A. Suchcitz, Informator Studium Polski Podziemnej 1947-1997, Londyn 1997, s. 10-11. 
sprawie polskiej ${ }^{84}$. Jednakże, jak podkreśla Andrzej Suchcitz, wobec tego, że władze wojskowe nie wykazywały większego zrozumienia dla spraw archiwalno-muzealnych (podobnie jak przed wybuchem wojny i w czasie jej trwania), to zawiązała się niezależna grupa inicjatywna zdecydowana zrealizować cel ochrony zasobu wojskowego ${ }^{85}$. To grono osób prywatnych powołało w pierwszych tygodniach 1945 r., początkowo nieformalnie, Instytut Historyczny im. gen. Władysława Sikorskiego, który w pierwszej kolejności zajął się zabezpieczeniem spuścizny po generale oraz prawnym ustaleniem własności wdowy Heleny Sikorskiej ${ }^{86}$. W maju 1945 r. Rada Ministrów zatwierdziła statut Instytutu. Po długich pertraktacjach odnośnie do składu Rady Instytutu, podczas pierwszego formalnego posiedzenia Rady 13 XII 1945 r., zatwierdzono pierwsze statutowe władze instytucji - prezesem został lord Elgin, prezes Towarzystwa Polsko-Szkockiego ${ }^{87}$. Dyrektorem instytutu wyznaczono ppłk. Borkowskiego, od początku mocno zaangażowanego w sprawę jego utworzenia. Kierownikiem archiwum Instytutu Historycznego został dr Edmund Oppman ${ }^{88}$, kierownik Archiwum SZ w Gasku, które jako jedno z pierwszych weszło w skład nowej placówki. Podstawą zbiorów archiwalnych były materiały zgromadzone przez Archiwum Sekretariatu Premiera (przemianowane na Departament Specjalny, Departament „S”) związane z działalnością gen. Sikorskiego, szczególnie „Dziennik Czynności Naczelnego Wodza”89. Podkreślano, że instytut ma mieć status instytucji społecznej w celu uniknięcia nacisków ze strony rządu warszawskiego oraz władz brytyjskich. W 1947 r. rozpoczęto gromadzenie archiwaliów, książek i muzealiów w siedzibie instytutu w Londynie, przy 20 Princes Gate, gdzie mieści się do dnia dzisiejszego.

W połowie 1945 r., kiedy tworzono podstawy instytutu, PSZ były bardzo rozbudowane organizacyjnie i rozproszone, co znajdowało odzwierciedlenie w działaniach archiwalnych. W Londynie działała Służba Archiwalno-Historyczna przy Ministerstwie Obrony Narodowej, w Szkocji, w Gasku funkcjonowało Archiwum i Muzeum SZ gromadzące materiały centralnych władz woj-

84 Z. Borkowski, dz. cyt., s. 146.

85 A. Suchcitz, Powstanie Instytutu Historycznego, s. 184.

${ }^{86}$ Por. Z. Borkowski, dz. cyt., s. 146-147.

87 Instytut Historyczny im. Gen. Sikorskiego, s. 4.

${ }^{88}$ Po jego śmierci w 1951 r. funkcję kierownika archiwum objęła jego żona Regina Oppmanowa, która jeszcze w latach wojny pracowała przy dzienniku czynności NW. S. Kuczyński, Regina Oppmanowa (29 I 1905-10 IX 1980), „Archeion”, t. 74, 1982, s. 249.

89 Guide to the Archives of the Polish Institute and Sikorski Museum, vol. 1, comp. and ed. W. Milewski, A. Suchcitz, A. Gorczycki, London 1985, s. XIII. 
skowych i $1 \mathrm{KP}$, ponadto w Neapolu było AMP Nr 1 gromadzące materiały 2 Korpusu, następnie AMP Nr 2 w Kairze gromadzące akta PSZ w ZSRR, APW oraz ataszatów wojskowych w państwach bałkańskich, dalej - Biuro Dokumentów w Rzymie zbierające relacje o tematyce polityczno-wojskowej, Biuro Historyczne Marynarki Wojennej i Biuro Historyczne Lotnictwa. Archiwa funkcjonowały również przy władzach państwowych i wojskowych na emigracji, przy każdym ministerstwie i urzędzie ${ }^{90}$.

Odrębny problem stanowiła dokumentacja wywiadu polskiego przechowywana w archiwach Oddziału II Sztabu NW i Oddziału II 2 KP. Materiały Oddziału II 2 KP (wraz z aktami Oddziału II Samodzielnej Brygady Strzelców Karpackich i APW) w 13 żelaznych skrzyniach aż do śmierci przechowywał u siebie w domu ostatni szef oddziału płk Wacław Bąkiewicz. Dopiero w 1972 r. trafiły do Instytutu Sikorskiego w Londynie ${ }^{91}$. Również do Instytutu przekazano akta Ośrodka Wywiadu Radiowego Oddziału II Sztabu NW ${ }^{92}$. Natomiast do dzisiaj niewyjaśnione są losy pozostałych materiałów Oddziału II Sztabu NW. Niewielka część została przekazana do Instytutu Historycznego im. gen. Sikorskiego, jeszcze mnie trafiło do Studium Polski Podziemnej w Londynie, szczątkowe materiały ocalały w spuściznach prywatnych oficerów „dwójki” stanowiących dzisiaj zasób archiwalnych wspomnianych placówek. Ślady prowadzą z jednej strony do archiwów brytyjskich, a z drugiej powtarzają się informacje o spaleniu przynajmniej ich części ${ }^{93}$.

Uchwałą emigracyjnej Rady Ministrów w maju 1945 r. polecono przekazanie większości zbiorów tych placówek do Instytutu Historycznego im. gen. Sikorskiego w Londynie ${ }^{94}$. Z kolei 27 VI 1945 r. dekretem Prezydenta RP na Uchodźstwie upoważniono dowódców jednostek wojsk lądowych, lotnictwa i marynarki do przekazywania na własności instytutowi posiadane pamiąt$\mathrm{ki}^{95}$. Jednak od strony formalnej podporządkowanie placówek archiwalno-muzealnych jeszcze kilka lat było dwutorowe. Z jednej strony - aż do likwidacji

90 M.in. przy Prezydium Rady Ministrów od grudnia 1941 r. funkcjonowało Archiwum Sekretariatu Premiera z zadaniem zabezpieczania akt urzędowych, materiałów pomocniczych i informacyjnych. E. Kołodziej, Archiwalia w Instytucie Polskim i Muzeum im. Gen. Sikorskiego w Londynie, „Archeion”, t. 95, 1995, s. 104.

91 Guide to the Archives of the Polish Institute an Sikorski Museum, s. 105-108.

92 A. Suchcitz, Archiwa wywiadu Polskiego po 1945 roku, „Zeszyty Historyczne” (Paryż), z. 89, 1989, s. 31.

93 Szerzej: tamże, s. 23-33.

94 B. Wroński, Centralne Archiwum na Obczyźnie, „Tydzień Polski” z 20 IV 1968, s. 7.

95 J. Zuziak, Wojskowa służba historyczna na obczyźnie 1939-2002, s. 59. 
wiosną 1949 r. - istniała Służba Archiwalno-Historyczna, której, za wyjątkiem Biura Dokumentów, podlegały wymienione placówki, z drugiej zaś pieczę nad dokumentami, eksponatami i innymi pamiątkami PSZ sprawował Instytut Historyczny im. Sikorskiego ${ }^{96}$. Ta dwutorowość sprawiała kłopoty, tym bardziej że niektórzy dowódcy rościli sobie prawo do samodzielnego dysponowania dokumentami wytworzonymi przez dowodzone przez nich jednostki ${ }^{97}$. Taka trudna sytuacja zaistniała w AMP Nr $2 \mathrm{w}$ związku z przekazywaniem materiałów do Instytutu gen. Sikorskiego. Generał Anders, do końca nieuświadomiony odnośnie do roli nowo powołanej instytucji, wstrzymał rozkaz dotyczący przekazania zbiorów z AMP Nr 2 wydany przez ppłk. Borkowskiego ${ }^{98}$. Kierownik archiwum Leon Koczy został ostro skrytykowany przez zwierzchników z 2 KP, gdy zamierzał ów rozkaz wykonać i było to jedną z przyczyn zwolnienia go ze stanowiska kierownika w grudniu 1945 r. Jego miejsce zajął mjr dr Ludwik Zakrocki, a Koczego mianowano zastępcą, by w marcu 1946 r. przenieść do Samodzielnego Referatu Historycznego Dowództwa Jednostek Wojska na Środkowym Wschodzie ${ }^{99}$. Zaletą wspomnianej podwójnej podległości było finansowanie przez wojsko działalności archiwalno-muzealnej, korzystanie przez Instytut Historyczny z pomieszczeń i personelu wojskowego i oczywiście pełnienie funkcji dyrektora instytutu oraz szefa Służby Archiwalno-Historycznej przez jedną osobę - ppłk. Zygmunta Borkowskiego.

Mimo różnych perturbacji przekazywanie akt do archiwum Instytutu Historycznego trwało. Część archiwaliów o „bezsprzecznym znaczeniu historycznym" decyzją dr. Oppmana kierowano do Archiwum Specjalnego (wewnątrz archiwum Instytutu Historycznego), którego objętość docelowo planowano na ok. 170 skrzyń z aktami. Jednocześnie Oppman apelował o jak najszybsze ich rozpoznanie i opracowanie wykazów, aby przystąpić do właściwego opracowania $^{100}$.

Dopiero w maju 1946 r. ostatecznie wyjaśniono nieporozumienia z dowództwem 2 Korpusu Polskiego. Generał Anders wyznaczył płk. dypl. Henryka Piątkowskiego na stanowisko łącznika w kontaktach z Instytutem Historycznym i podjął decyzję o przekazaniu do Londynu zbiorów i pamiątek

96 A. Suchcitz, Powstanie Instytutu Historycznego, s. 190.

97 Władze wojskowe ostatecznie ustąpiły dopiero w 1947 r. E. Kołodziej, dz. cyt., s. 107.

98 A. Suchcitz, Powstanie Instytutu Historycznego, s. 192.

99 R. Stobiecki, dz. cyt., s. 279-280.

100 A. Suchcitz, Naczelny archiwista emigracji: Edmund Oppman, „Tydzień Polski” z 7 X 1995, s. 11. 
muzealnych $2 \mathrm{KP}^{101}$. Jednocześnie władze Korpusu podjęły działania odnośnie do wewnętrznego uregulowania pracy historyczno-archiwalnej - przy czym jej istota miała obejmować pracę historyczną, a archiwalia traktowano jako materiał pomocniczy, chociaż niezbędny do jej prowadzenia. Ramy organizacyjne tych prac określone 17 V 1946 r. przewidywały nadzorowanie ich przez szefa sztabu Korpusu przy pomocy Samodzielnego Referatu Historycznego, w obowiązkach którego było „czuwanie nad archiwami w sensie zabezpieczenia ich zbiorów i korzystania z nich do prac"102. Planowano powołać ciało doradcze w postaci Rady Naukowo-Historycznej, która m.in. miała opiniować projekty instrukcji i zarządzeń w sprawach historyczno-archiwalnych. Stałe komórki wykonawcze prac historyczno-archiwalnych obejmowały również Oddział Wojskowo-Historyczny zorganizowany na filarach Komisji Doświadczeń Wojennych, w którym skupiały się prace naukowe dotyczące głównie działań $2 \mathrm{KP}$, ale również zbieranie relacji oraz gromadzenie doświadczeń wojennych i ich „przepracowywanie”. Faktycznie powstała Sekcja Historyczna 2 Korpusu, którą kierował płk dypl. Stanisław Biegański ${ }^{103}$. Ponadto wykonywanie wspomnianych prac odbywało się w Biurze Dokumentów, AMP Nr 1 i AMP Nr 2, Samodzielnym Referacie Historycznym przy Dowództwie Jednostek Wojska na Środkowym Wschodzie oraz w kwatermistrzostwie. Obowiązki w tym zakresie nałożono również na oficerów referentów ds. historycznych w dowództwach wielkich jednostek i kronikarzy oddziałowych.

Interesujący był odzew na decyzje w sprawach archiwalnych zapadające w Wielkiej Brytanii czy we Włoszech ze strony bezpośrednio zainteresowanych, czyli kierowników archiwów. Kapitan dr Walerian Charkiewicz kierujący AMP Nr 1 w sierpniu 1946 r. podkreślał, że nie wystarczy polecenie przekazania zbiorów i likwidacja placówek, uznając to za cel zbyt krótkowzroczny. Niezbędny był dobry plan z jasno określonym celem, gdyż chodziło m.in. podział zbiorów między Archiwum i Muzeum SZ oraz Instytut Historyczny im. gen. Sikorskiego, a relacje między nimi nie zostały od razu jasno określone. Ponadto zwracał uwagę, że projekt organizacji Służby Archiwalno-Muzealnej ${ }^{104}$ zdezaktualizował się m.in. w związku z napływem do AMP Nr 1 dużej liczby akt, co

101 Tenże, Powstanie Instytutu Historycznego, s. 192.

102 Ramy organizacji prac historyczno-archiwalnych w 2 Korpusie z 17 V 1946 r., AIPMS, 2 KP, sygn. A.XI.67/27.

103 R. E. Stolarski, Pułkownik dyplomowany dr Stanisław Biegański. Żołnierz i historyk (1894-1994), „Teki Historyczne” (Londyn), t. 21, 1994-1995, s. 14.

104 Nazewnictwo występujące w dokumentach jest zróżnicowane i dość dowolne, dlatego obok Służby Archiwalno-Historycznej pojawia się Służba Archiwalno-Muze- 
diametralnie zmieniło punkt widzenia ${ }^{105}$. Propozycje Charkiewicza nie miały żadnego przełożenia na decyzje zwierzchników i we wrześniu 1946 r. zbiory archiwum były przygotowane do wysyłki do Wielkiej Brytanii, w tym archiwalia obejmujące 60 skrzyń akt sądowych, 48 skrzyń akt szpitalnych, 33 skrzynie z mapami i dokumentami Służby Geograficznej, 4 skrzynie z wnioskami odznaczeniowymi oraz skrzynię z aktami Biura Rozrachunkowego ${ }^{106}$.

Plan ostatecznej likwidacji komórek archiwalno-muzealnych PSZ oraz zabezpieczenia ich zbiorów przyjęto podczas konferencji w Londynie 22 IV 1946 r. ${ }^{107}$ Postanowiono, że wszystkie komórki archiwalno-muzealne 2 KP wraz z AMP Nr 1 i Biurem Dokumentów oraz AMP Nr 2 zostaną skupione w Foxley Canadian Camp (hrabstwo Hereford). Do czasu ostatecznej likwidacji, czyli 31 XII 1947 r., miały one przejąć od likwidowanych jednostek i instytucji $2 \mathrm{KP}$ wszelkie akta, dokonać ich segregacji, wydzielając te o wartości historycznej i niszcząc bezużyteczne, oraz zwrócić żołnierzom depozyty.

Mimo że w marcu 1947 r. został podpisany protokół o przejęciu mienia Służby Muzealnej na własność Instytutu gen. Sikorskiego ${ }^{108}$, to negocjacje w tych sprawach trwały aż do końca tego roku ${ }^{109}$. Nie udało się do końca zrealizować skupienia w Instytucie im. gen. Sikorskiego wszystkich archiwaliów wytworzonych przez jednostki i organy wojskowe oraz gromadzonych przez różne placówki archiwalno-muzealno-historyczne. Nie sprzyjał temu klimat polityczny, część osób przekonano do powrotu do kraju, a wraz z nimi wróciły materiały historyczne, część przekazywano do innych placówek, także zagranicznych. Archiwalia przetrzymywały urzędy i instytucje, a także wielu do-

alna, której formalnie nie było, ale muzea wojskowe funkcjonowały wspólnie z archiwami i bibliotekami.

105 Planując, obliczano zasób archiwum na 150 skrzyń, który faktycznie zwiększył się do 670 skrzyń; eksponaty muzealne wzrosły z 4000 do 7102, książki z 2413 do 3561 egzemplarzy, fotografie z 748 do 948 sztuk - i liczby te całe czas rosły. Uwagi i wnioski W. Charkiewicza odnośnie do projektu organizacji Służby Archiwalno-Muzealnej z 23 VIII 1946 r., AIPMS, 2 KP, sygn. A.XI.67/27.

106 Informacja W. Charkiewicza dla kierownika samodzielnego Referatu Historycznego 2 Korpusu z 21 IX 1946 r., AIPMS, 2 KP, sygn. A.XI.57/2.

107 Raport S. Biegańskiego dla szefa Komisji Likwidacyjnej 2 Korpusu z 26 IV 1947 r., AIPMS, 2 KP, sygn. A.XI.67/27.

108 A. Suchcitz, Powstanie Instytutu Historycznego, s. 192.

109 Tenże, O Instytucie Polskim i Muzeum im. Gen. W. Sikorskiego, „Pamiętnik Literacki" (Londyn), t. 13, 1988, s. 35-45. 
wódców ${ }^{110}$. Andrzej Suchcitz pisze, że czasem wynikało to z braku zaufania do nowej placówki ${ }^{111}$.

Nie do końca można szczegółowo odtworzyć dzieje archiwaliów przywiezionych na ziemię brytyjską, gdyż nie odbywało się to całkiem zgodnie z planami Służby Likwidacyjnej 2 KP. Archiwalia dotyczące tego zagadnienia są niekompletne. Na liście pracowników AMP Nr 2 w sierpniu 1947 r. figuruje zarówno Jan Adamus, jak i Leon Koczy ${ }^{112}$, który dopiero co przybył z Bliskiego Wschodu. Adamus od września do grudnia 1947 r. pracował w AMP nr 1 w Foxley w Anglii ${ }^{113}$. W biografii Adamusa pojawia się jeszcze jedno miejsce pracy - Archiwum PSZ Grupa B w Hursley k. Winchesteru w Anglii, gdzie pracował do czerwca 1948 r., a następnie na własną prośbę zwolniony z wojska wrócił do Polski. Wspomniana „Grupa B” lub „grupa akt B”, jak pisał Leon Koczy do ppłk. Borkowskiego w listopadzie 1948 r., dostała się w ręce administracji polsko-brytyjskiej ${ }^{114}$. Z kolei AMP Nr 2 zostało ewakuowane do Szkocji i jako filia Instytutu Historycznego im. gen. Sikorskiego mieściło się w Banknock House koło Falkirk ${ }^{115}$. Kierownikiem tej instytucji został Leon Koczy ${ }^{116}$. Po zamknięciu filii z przyczyn finansowych w 1960 r. Archiwum zlikwidowano, a zbiory rękopiśmienne przekazano centrali Instytutu w Londynie. Część druków i muzealiów przesłano do Polski, a resztę umieszczono w Glasgow, dokąd przeniósł się m.in. Leon Koczy z małżonką Marią. W domu zakupionym częściowo z pieniędzy Instytutu Sikorskiego, a częściowo z prywatnych funduszy małżeństwa Koczych mieściła się Biblioteka i Oddział Instytutu Historycznego im. gen. Sikorskiego ${ }^{117}$.

Do Instytutu gen. Sikorskiego nie przekazano materiałów Biura Dokumentów $2 \mathrm{KP}$ z powodu obaw gen. Andersa, że ziemia brytyjska nie jest bezpiecznym miejscem dla dokumentów, które mogą być wykorzystane przez wrogów. Chodziło o fakt przechowywania tam ponad 18 tys. relacji i ankiet dotyczą-

110 Te najczęściej weszły w skład spuścizn prywatnych i w raz z nimi były przekazywane do placówek archiwalnych, bibliotek lub muzeów.

111 A. Suchcitz, Powstanie Instytutu Historycznego, s. 192.

112 Personel AMP Nr 2, 14 VIII 1947 r., AIPMS, 2 KP, sygn. A.XI.67/27.

113 Z. Rymaszewski, dz. cyt., s. 21.

114 Cyt. za: R. Stobiecki, dz. cyt., s. 282.

115 Tamże.

116 Leon Koczy po przybyciu do Wielkiej Brytanii wstąpił do Polskiego Korpusu Przysposobienia i Rozmieszczenia, następnie zamieszkał w Szkocji, pracując jako historyk i bibliotekarz, działając w towarzystwach naukowych. Zmarł w 1981 r. R. Stobiecki, dz. cyt., s. 279.

117 Tamże, s. 283. 
cych zbrodni i przestępstw sowieckich, za co ankietowanym, a szczególnie ich rodzinom w kraju mogły grozić represje ${ }^{118}$. Dlatego w latach 1946-1948 trafiły one jako depozyt do Instytutu Hoovera Uniwersytetu Stanforda w Kalifornii, przekazane tam przez Józefa Garlińskiego na polecenie gen. Andersa, który przedstawił się jako jego wyłączny właściciel119.

Chociaż czas wojny nie sprzyjał pracy archiwalnej, to nie tylko ratowano zagrożone archiwalia, wywożąc je z kraju, ale również wraz z powoływaniem każdej, kolejnej formacji PSZ, organizowano przy nich komórki historyczno-archiwalno-muzealne. Różnie natomiast było ze zrozumieniem dla pracy archiwistów oraz idei ochrony dokumentacji. Nic nie stało na przeszkodzie, aby wsłuchać się w ich głosy nawołujące m.in. do zabezpieczania dowodów na udział Polaków w walce z Niemcami i skuteczniej egzekwować wydawane w sprawach archiwów rozkazy. Jednak generalnie, podobnie jak przed wybuchem wojny, ani archiwów, ani archiwistów i ich pracy nie doceniano. Archiwalia traktowano utylitarnie, jako materiał badawczy dla historyków i raczej zgodnie z hasłem „potrzebne tu i teraz”, jako materiał wykorzystywany w celach propagandowych, a nie jako zasób, który współcześnie nazywamy dziedzictwem narodowym.

W ostatni rok II wojny światowej archiwa w PSZ wkroczyły w stanie rozproszonym i - jak wynika z zachowanych dokumentów - dość zaniedbywane przez najwyższe władze wojskowe. Stąd cenna inicjatywa grupy osób uwieńczona powołania Instytutu Historycznego im. gen. Sikorskiego. „Ambicją i dążeniem Archiwum Instytutu jest zgromadzić u siebie wszystkie inne, rozproszone jeszcze po świecie materiały, dotyczące spraw polskich z okresu ostatniej wojny, by stworzyć w ten sposób pewną całość archiwalną, która stałaby się kompletnym źródłem do badania niedawnych dziejów polskich" pisał w 1957 r. Wacław Sikorski ${ }^{120}$. Jakkolwiek to życzenie (marzenie) zgromadzenia w jednym miejscu archiwaliów polskich nie mogło się spełnić, to właśnie ta placówka zgromadziła największy zbiór materiałów emigracyjnych i pozostaje dzisiaj największym ośrodkiem archiwalnym poza granicami kra-

118 Depozyt był niedostępny do śmierci gen. Andersa w 1970 r. W. Stępniak, dz. cyt., s. 180 .

119 Tamże.

120 W. Sikorski, Czym jest dla Polaków Instytut Historyczny imienia Generała Sikorskiego, [w:] Instytut Historyczny imienia Generała Sikorskiego, s. 14. 
ju. Dzieło ochrony archiwaliów emigracyjnych podjęły i kontynuują także inne instytucje polskie zagranicą oraz w Polsce ${ }^{121}$.

\section{Archiwalia}

Archiwum Instytutu Polskiego i Muzeum im. gen. Sikorskiego w Londynie

- Akta z obozów internowanych. Dowództwo Obozów WP na terenie Rumunii

- Armia Polska we Francji 1939-1940. Wojskowe Biuro Historyczne w Paryżu

- 2 Korpus Polski

- Relacje z Kampanii 1939 roku.

\section{- Literatura}

Anders W., Bez ostatniego rozdziału. Wspomnienia z lat 1939-1946, Londyn 1960.

Bardach J., Jan Adamus (1896-1962) - próba charakterystyki naukowej, „Czasopismo Prawno-Historyczne", t. 15, 1963, z. 1.

Bardach J., Jana Adamusa wspominam..., „Czasopismo Prawno-Historyczne”, t. 49, 1997.

Borkowski Z., Wspomnienia, „Zeszyty Historyczne” (Paryż), z. 33, 1975.

Bujniewicz N., Zajas A., Bronisław Pawłowski i Bolesław Waligóra - szefowie Archiwum Wojskowego w 20-leciu międzywojennym, [w:] Wkład archiwistów warszawskich w rozwój archiwistyki polskiej, red. A. Kulecka, Warszawa 2012.

Ciesielski J., Wawrzyński T., Waligóra Bolesław, [w:] Słownik biograficzny archiwistów polskich, t. 2: 1906-2001, red. B. Woszczyński, Warszawa 2002.

Grajewski H., Jan Adamus (1896-1962), „Zeszyty Naukowe Uniwersytetu Łódzkiego”, seria I, z. 31, 1963.

Guide to the Archives of the Polish Institute and Sikorski Museum, vol. 1, comp. and ed. W. Milewski, A. Suchcitz, A. Gorczycki, London 1985.

Instytut Historyczny im. Gen. Sikorskiego 1945-1962, Londyn 1962.

Instytut Józefa Piłsudskiego w Ameryce i jego zbiory, oprac. J. Cisek, Warszawa 1997.

Kołodziej E., Archiwalia w Instytucie Polskim i Muzeum im. Gen. Sikorskiego w Londynie, „Archeion”, t. 95, 1995.

Koranyi K., Jan Adamus (1896-1962), „Kwartalnik Historyczny”, R. 70, 1963.

Kuczyński S., Regina Oppmanowa (29 I 1905-10 IX 1980), „Archeion”, t. 74, 1982.

Kukiel M., Słowo wstępne, [w:] Instytut Historyczny imienia Generała Sikorskiego 1945-1957, Londyn 1957.

Librewski S., Początki centralnego archiwum na obczyźnie, „Tydzień Polski” z 27 IV 1968.

121 Por. W. K. Roman, Archiwalia prywatne polskich emigrantów - problemy gromadzenia, przechowywania, opracowania i udostępniania, „Archiwista Polski”, 2015, nr 2, s. 35-51. 
Łokaj B., Likwidacja Polskich Sit Zbrojnych 1945-1946, „Zeszyty Historyczne” (Paryż), z. 35, 1976.

Manteufflowa M., Edmund Oppman, [w:] Polski słownik biograficzny, t. 24, red. E. Rostworowski, Wrocław-Kraków 1979.

Oppman E., Historia powstania Instytutu Historycznego imienia generała Sikorskiego, jego cele i zadania, [w:] Instytut Historyczny imienia Generała Sikorskiego 1945-1957, Londyn 1957.

Oppmanowa R., Archiwum, [w:] Instytut Historyczny imienia Generała Sikorskiego 1945-1957, Londyn 1957.

Roman W. K., Archiwalia prywatne polskich emigrantów - problemy gromadzenia, przechowywania, opracowania i udostępniania, „Archiwista Polski”, 2015, nr 2.

Roman W. K., Centralne Archiwum Wojskowe 1918-1998. Tradycje, historia, współczesność służby archiwalnej Wojska Polskiego, Toruń 1999 (i nast.).

Roman W. K., Losy polskich akt wojskowych po wybuchu II wojny światowej - epizod rumuński 17.09-19.11.1939 r. (w druku).

Roszkowski W., Historia Polski 1914-2005, Warszawa 2007.

Rymaszewski Z., Adamus Jan, [w:] Słownik biograficzny archiwistów polskich, t. 1: 1918-1984, red. M. Bielińska, I. Janosz-Biskupowa, Warszawa-Łódź 1988.

Sikorski W., Czym jest dla Polaków Instytut Historyczny imienia Generała Sikorskiego, [w:] Instytut Historyczny imienia Generała Sikorskiego 1945-1957, Londyn 1957.

Stępniak W., Archiwalia polskie w zbiorach Instytutu Hoovera Uniwersytetu Stanforda, Warszawa 1997.

Stobiecki R., Leon Koczy, „Teki Historyczne” (Londyn), t. 23, 2004.

Stolarski R. E., Pułkownik dyplomowany dr Stanisław Biegański. Żołnierz i historyk (1894-1994), „Teki Historyczne” (Londyn), t. 21, 1994-1995.

A. Suchcitz, Archiwa wywiadu Polskiego po 1945 roku, „Zeszyty Historyczne” (Paryż), z. 89, 1989.

Suchcitz A., Informator Studium Polski Podziemnej 1947-1997, Londyn 1997.

Suchcitz A., Major Bolesław Andrzej Waligóra - pionier polskiej archiwistyki wojskowej, „Biuletyn Wojskowej Służby Archiwalnej”, nr 26, 2003.

Suchcitz A., Naczelny archiwista emigracji: Edmund Oppman, „Tydzień Polski” z 7 X 1995.

Suchcitz A., O Instytucie Polskim i Muzeum im. Gen. W. Sikorskiego, „Pamiętnik Literacki" (Londyn), t. 13, 1988.

Suchcitz A., Powstanie Instytutu Historycznego im. Gen. Sikorskiego w Londynie 1945-1949, [w:] Idea Europy i Polska w XIX i XX wieku, red. J. Degler i in., Wrocław 1999.

Suchcitz A., Sprawa odtworzenia Archiwum Wojskowego we Francji w 1940 r., „Teki Historyczne" (Londyn), t. 21, 1995.

Szczurowski M., Mity, rytuały, symbole a żołnierz polski w przestrzeni politycznej II wojny światowej, Toruń 2013.

Tymieniecki K., Jan Adamus (1896- 1962), „Roczniki Historyczne”, t. 30, 1964.

Wroński B., Centralne Archiwum na Obczyźnie, „Tydzień Polski” z 20 IV 1968.

Zamorski K., Dwa tajne Biura 2 Korpusu, Londyn 1990. 
Zuziak J., Generał dywizji Marian Kukiel jako minister obrony narodowej (1942-1949), „Teki Historyczne” (Londyn), t. 21, 1994-1995.

Zuziak J., Wojskowa służba historyczna na obczyźnie 1939-2002, [w:] Z dziejów służby historycznej Wojska Polskiego 1918-2002, Warszawa 2002.

Żaroń P., Armia Andersa, Toruń 1996.

\section{Summary}

Archives of the Polish Armed Forces in the West

A result of a defeat of the Polish state during the September Campaign in 1939 was an exodus abroad of hundreds of thousands of Polish citizens. During internment in Romania archivists from the evacuated Military Archive put forward a proposal to organize an archival service adapted to the war conditions to preserve materials taken out of Poland, as well as those constantly created in military institutions set up in exile. As a part of the Polish fight against the Reich, regular military formations called the Polish Armed Forces in the West were organized at the Allies' side. Every formation had a section of an archival/historical/museum character. There were: the Archival Office in the recreated Military Historical Bureau in the Polish Army in France; the Archive of the Bureau of the Commander-in-Chief in London; historical-archival sections in British air force and navy; the Independent Historical Office of the Polish Armed Forces attached to Command of the Armed Forces in the USSR; the Archive of the Polish Army in the Middle East; the Archive of the Polish Army in the East; the Field Archive and Museum No. 1 of the Polish II Corps; the Field Archive and Museum No. 2; the Archive of Information Unit of the Polish II Corps. The quantity of such initiatives did not always translate into quality of work of archives and archivists. There were attempts to centralize management of the Polish Armed Forces archival and museum institutions; the Archive and Museum of the PAF in Scotland was set up in 1942, but it could not fulfill its duties due to lack of interest from the highest military authorities. Similar situation occurred with the Archival-Historical Service of the PAF, set up in January 1945. In May 1945 an initiative of a group of people succeeded, and they created the General Sikorski Historical Institute in London. This initiative managed to collect in one place - as far as it was possible - materials created by the Polish military and civilian institutions in exile. 
